\title{
Politics and Management of Primary Schools in Uyo Educational Zone: Implications for National Development
}

\author{
Ndifreke Okon Jonah ${ }^{1 *}$, Kingsley E. Nwachukwu, Ph.D², Egberibine Yekedu Nanah ${ }^{2}$, \\ Dr. Immaculata Gregory Umoh ${ }^{4}$ \\ ${ }^{1,2}$ Department of Early Childhood and Special Education, Uyo \\ ${ }^{3}$ Dept. of Earlychildhoodcare and Education, Isaac Jasper Boro College of Education, Saagbama Bayelsa State \\ ${ }^{4}$ Dept. of Earlychildhood and Special Education, University of Uyo, Uyo
}

\section{*Corresponding Author}

Ndifreke Okon Jonah

\section{Article History}

Received: 05.01.2021

Accepted: 18.01 .2021

Published: 09.02.2021

\begin{abstract}
This study investigated the influence of politics on the management of primary schools in Uyo Educational Zone. Three research questions and three null hypotheses were postulated to guide the study. Descriptive survey research design was used for this study. The population of the study was 3,411, made up of 3,239 classroom teachers and 172 head teachers. The sample size for the study was 463 respondents, made up of 344 classroom teachers and 119 head teachers selected through simple random sampling technique. The instrument for data collection was the questionnaire titled; Politics and Primary School Management Questionnaire (PPSMQ). Three experts validated the instrument, while Cronbach Alpha statistic was used to compute the reliability coefficient of the instrument, which yielded 0.80. Mean and standard deviation were used to answer the research questions while t-test statistic was used to test the hypotheses at 0.05 probability level. The finding showed that there was a significant influence of politics on the management of primary schools in Uyo Educational Zone. Based on the findings of the study, it was recommended among others that government should ensure that there are no favouratism in the disbursement of funds to primary schools, as politics was bound to adversely affect the provision of management of funds in primary schools. The government should avoid quota system in the provision of facilities and equipment in schools.
\end{abstract}

Keywords: Politics, Management, Primary Schools and National Development.

\section{INTRODUCTION}

Nigeria is a highly politicalized society with diverse, ethnic, geographical and religious interests. The role of politics in the management of secondary schools in Nigeria is affected by the government interference. This is because politics and school management cannot be separated. The objectives of education, the control, production, process variables, financial and accreditation system are tied inseparably to politics. The concept of politics has been well articulated by educators and social scientists including Ogbonnaya [1] and Okeke [2].They both agree that politics is not restricted to political parties but is there in Nigeria banks, markets, and military establishments, commercial and industrial sectors of our economy and even in educational institutions. These experts have variously defined politics. Ogbonnaya [3] sees it as a subject concerned with attracting, securing and maintaining the wellbeing of a community, state or nation. Okeke [2] sees it as a device intended for finding solutions to social, economic, political and educational problems by political means. However, Uchendu [4] on the other hand sees "politics as the science and act of securing and advancing the temporal welfare of a community organized as a state." The business of politics, therefore, involves both the laying down of general principles and their application to concrete problems. The scope of politics is the temporal wellbeing of the community as a whole. These definitions imply that politics is concerned with attracting, securing and maintaining the wellbeing of a community. The definitions also suggest that politics is an instrument for finding solutions to social, economic, scientific, technological and educational problems of a nation.

Copyright (9) 2021 The Author(s): This is an open-access article distributed under the terms of the Creative Commons Attribution 4.0 International License (CC BY-NC 4.0) which permits unrestricted use, distribution, and reproduction in any medium for noncommercial use provided the original author and source are credited. 
The implication of all of the above is that politics is an unavoidable phenomenon in every society. Politics is allembracing; it deals with power and power involves elements of decision making, allocating of resources, settlement of conflicts, provision of social amenities as well as the provision and management of education. Hence, no society can think about having an established government without politics. It is the interference of stakeholders including the government, community, members of the school board, school board of governors and the parent teachers association in the management of primary schools in the Uyo Educational Zone. Politics cannot be separated from primary school management. It is for this reason that Okeke [2] stated emphatically that politics plays an important role in decision making, control and governance of primary schools. Furthermore, Okeke pointed out that politics in education can be looked at as a process of control, decision making, implementation, management, governance and a method by which resources are allocated to different ethnic groups to achieve their aims. The role of politics is heightened in view of the fact that an educational system has political goals and these goals are essential to justify the existence of the system and the political order of society. In other words, the political order initiates good education.

It has been observed that politics is capable of having some influences in the management and policies that guide education. Politics may influence policies on funding, staff-personnel administration, provision of basic infrastructurelequipment and school-community relation [5]. When the political influence is favourable to management and the development of education, it is regarded as positive but when the interference of government is inimical to the rules and regulations of the school management, it is negative because the state of objective of secondary education will not be achieved, therefore, teaching and learning will not be effective. Therefore, politics in the context of this study is a situation where political consideration is given preference rather than due process in which case the running of a school is influenced by the wishes of those in power rather than by established guidelines. In other words, it is a situation where due process is circumvented by pressure from groups of individuals in powerful positions. This undue influence results in school management deviating from normal or formal administrative principles and guidelines, hence, the management of primary schools is influenced by government interference. The question at this juncture is what is management?

Management has so many definitions and has been described in diverse ways. According to Peretomode [6], management is a set of activities which can be classified as concerned with the process of planning, organizing, controlling, directing and staffing. All these are towards the achievement of the goals and objectives of the organization. Also, management is a way of guiding, leading and controlling the efforts of a group of people towards the realization of their common goals and objectives [7]. Hence, in this context management is the use of materials and non-materials resources in an organization to achieve stated goals. In this present study, schools are organized places with rules and regulation guiding the activities of what is going on, in order to achieve the desired goals of education. In agreement with the above, Peretomode [6] revealed that school management is the process of planning and formulation of educational policies or programme with a view to achieving the educational goals, Peretomode stated categorically that, school management is the application of the process of planning, organizing, coordinating, controlling and evaluating human and material resources to achievement goals of education. Therefore, the importance of school management is for effective utilization of material and non-material resources to achieved predetermined goals. Primary schools management has a multiple link with the society and each sector of the society likes to influence the management of primary school to suit their relationship within the society. These include federal government, state government, local government, parent teachers association, organizations, religious bodies and philanthropic. Within the school management system, various agencies, external and internal forces influence stated policies and the stated rules and regulation of the school. The external agencies include government policy, pressures from environment and all these affects school management in achieving their aims and objectives while the internal agencies includes pressures from teachers, parents and community. However, interference of both the government and other agencies affects the smooth running of the school programme in areas like funding, staff personnel, provision of basic infrastructures/equipment and school community relation which this study intends to cover.

Funding as observed by Ogbonnaya [1] is concerned with procuring, expending, accounting and maintaining the financial resources of an educational institution efficiently to achieve educational objectives. The achievements of educational goals depends on adequate financial support of the government, organizations, individual and even communities, because adequate financial supply and maintenance makes the school to reach its glory and ensure adequate personnel to work in an organization. In order to achieve the stated objectives of school management, there is the need for adequate staff personnel management to work in the organization. Oboegbulem [8] viewed staff personnel administration as the manpower or human resources management in an organization. Oboegbulem pointed out that staff personnel refers to manpower activities of any organization which embraces recruitment of staff, staff maintenance, selection, induction, motivation, appraisal, developmental, discipline, training, compensations and evaluation of staff for education activities. In a school system, the overall goals of the personnel administration is to recruit adequate and qualified staff, develop and maintain the staff so that they would be able and willing to render effective and efficient educational services to the pupils. In primary school setting, staff personnel administration forms an important responsibility of the school management in achieving the goals of the schools in particular and of education in general. 
The term school facilities/equipment refers to the school site, buildings, play grounds, equipment and other material resources provided in the school for effective teaching and learning operations [9]. Then activities of the schools are evaluated and expressed through the quality of facilities in the school e.g. the quality of teachers, building, playground, and computers and so on. This is done because education is necessary condition for progress, eradication of ignorance, superstition and poverty in the community and society at large. In addition, school community relations can be described as the degree of understanding and goodwill achievement between the school and the community [8]. This is in line with views of Ogbonnaya [5] that the relationship between the school, the community and the ruling political parties are guided by policies and decision which affect the school management positively/or negatively. It has been observed that interference of government is having some influences on the management and policies that guide school management.

Government interference influence policies on funding, staff personnel administration, provision of basic infrastructures/equipment and school community relation. When the influence are favourable to school management, development, and progress to achieve their goals, it is regarded as positive because the management have adequate supply of all its needs to achieve their goals, but when the influence is unfavourable to the management, it is regarded as negative because the interference of the government is affecting the smooth running of teaching and learning making it impossible to achieve the goals of the school management. Therefore, the stated objectives will not be achieved. Furthermore, one may describe the influence as positive when proper decisions are taken in the distribution of resources, appointment of head teachers, allocation of funds to schools, appointment of staff personnel, good relation of school community and proper welfare of pupils. The influence is negative where there is discrimination, favourism, and bias in the appointment of head teachers, promotion of teachers, and allocation of funds and lack of freedom on the parts of the head teachers, teachers, and school-community relation to express their opinions on matters affecting them. Therefore, government interference in school management to a large extent has influence the management in different ways. It is observed that in areas of employment within education sector, politics to a large extent determines who is to be taken and who is not to be employed. Eze [10] observed that in the distribution of infrastructural facilities to schools, the issue of politics also is paramount. The issue of politics in transfers of teachers and principals is alarming to the extent that one is made to stay in an urban area if he/she has a God-father. Also, because of politics on the control, management and governance of schools, the issue of funding, staff personnel, provision of basic infrastructures/equipment and school community relation has made various agencies to have interest in school management. Therefore the stated rules and regulation guiding the school management is being influenced by politics. This study intends to determine the influence of politics on the management of primary schools in Uyo Educational Zone.

\section{Statement of the Problem}

Politics can be a vital factor that influences decisions in the management of primary schools in various situations. Since the government has taken over the control and management of primary schools, political issues, societal interest and environmental influences on the management of primary schools have come to the fore. Primary education has a link with society; hence each segment of society tries to interfere with the management of primary schools to suit their roles in the society. The belief that politics influences the allocation of funds, staff management, provision of basic infrastructure/equipment and school community relation is common among the people of Uyo Educational Zone. Political influences have positive and negative impact on teaching and learning in schools. In the society, it seems that the management of primary schools is a fertile ground for politicking and politicians influence the management of primary education while the head teachers, teachers, PTA of each school obey them to a fault.

This servile attitude makes it impossible for head teachers and teachers to stand their grounds to make demands for their salaries, allowances, promotions, car loans and conducive teaching environment. They embark on strike actions that often yield nothing worthwhile. Teachers, parents and head teachers observe that politics influence primary school management in areas such as in transfer of teachers, promotion of head teachers, fund allocation, distribution of facilities, upgrading of schools and conduct of examinations. These observations have no empirical backing so far. Some primary schools in the Uyo Educational Zone is known to be doing well with good equipment and adequate infrastructure while others unfortunately suffer serious deprivations. Can the popular belief that there is a significant political interference in the running of primary schools be substantiated? Although, there are a number of researches directed at politics and its consequences in relation to educational policies and National development, none so far has been specific on the perceived impact of politics and political parties on educational management as a benchmark for improvement. Hence, the problem of this study is what is the influence of politics on the management of primary schools in the Uyo Educational Zone?

\section{RESEARCH QUESTIONS}

i. To what extent do head teachers and classroom teachers' response on the influence of politics on the funding of primary schools in Uyo Educational Zone? 
ii. To what extent do head teachers and classroom teachers' response on the influence of politics on the staff personnel administration of primary schools in Uyo Educational Zone?

iii. To what extent do head teachers and classroom teachers' response on the influence of politics on the provision of basic infrastructure and equipment in primary schools in Uyo Educational Zone?

iv. To what extent do head teachers and classroom teachers' response on the influence of politics on the school community relations of primary schools in Uyo Educational Zone?

\section{RESEARCH HYPOTHESES}

H0: $\quad$ There is no significant difference in the mean response scores of the head teachers and classroom teachers on the influence of politics on the funding of primary schools.

$\mathbf{H 0}_{2}$ : There is no significant difference in the mean response scores of the head teachers and classroom teachers on the influence of staff personnel administration of primary schools.

$\mathbf{H 0}_{3}$ : There is no significant difference in the mean response scores of the head teachers and classroom teachers on the influence of provision of basic infrastructure and equipment in primary schools.

H04: There is no significant difference in the mean response scores of the head teachers and classroom teachers on the influence of school community relations of primary schools.

\section{RESEARCH METHOD}

A descriptive survey research design was adopted for the study and was carried out in

Uyo Educational Zone, Akwa Ibom State. The Educational Zone is made up of four local

Government Areas namely Uyo, Ibesikpo Asutan, Uruan and Nsit Atai. The population of the study was 3,411, made up of 3,239 classroom teachers and 172 head teachers. The sample size for the study was 463 respondents, made up of 344 classroom teachers and 119 head teachers selected through simple random sampling technique. The instrument for data collection was the questionnaire titled; Politics and Primary School Management Questionnaire (PPSMQ). It consisted two sections A and B. Section A elicited information on demographic data and section B elicited information on influence of Politics on Primary Schools Management. It was structured four point scale response format of Very High Extent (VHE), High Extent (HE), Low Extent (LE) and Very Low Extent (VLE). To ascertain the face validity of the Questionnaire, the items were given to three experts, one from Measurement and Evaluation, one from Educational Administration and Planning and one from Political Science Education all from the University of Uyo, Uyo. Their corrections and comments were used to modify the questionnaires. To determine the internal consistency of the instrument, trial testing was carried out using 15 respondents ( 3 Head teachers and 12 Classroom teachers) from the study area. Cronbach Alpha was used to determine the internal consistency of the items which yielded reliability coefficient index of 0.80 , which is an indication that the instrument is reliable. Based on the geographical spread of the population, the researcher employed and trained four research assistants, one from each Local Government Area. The assistants were directed on the modality for administering and collecting the instrument. The assistants were directed to administer the questionnaire on the respondents and retrieve them the same day. Mean and standard deviation were used to answer the four research questions. Based on the response format of the four point pattern, mean scores of 3.50-4.49 was taken as VHE, 2.50-3.49 was taken as HE, 1.50-2.49 was taken as LE and 0.50-1.49 was taken as VLE. In testing the null hypothesis, the t-test statistic was used at 0.05 level of significance.

\section{RESULTS}

\section{Answering Research Questions}

\section{Research Question 1}

To what extent do head teachers and classroom teachers' response on the influence of politics on the funding of primary schools in the Uyo Educational Zone? 
Table-1: Mean and standard deviation of head teachers and classroom teachers' response on the influence of politics on the funding of primary schools in the Uyo Educational Zone $n=463$

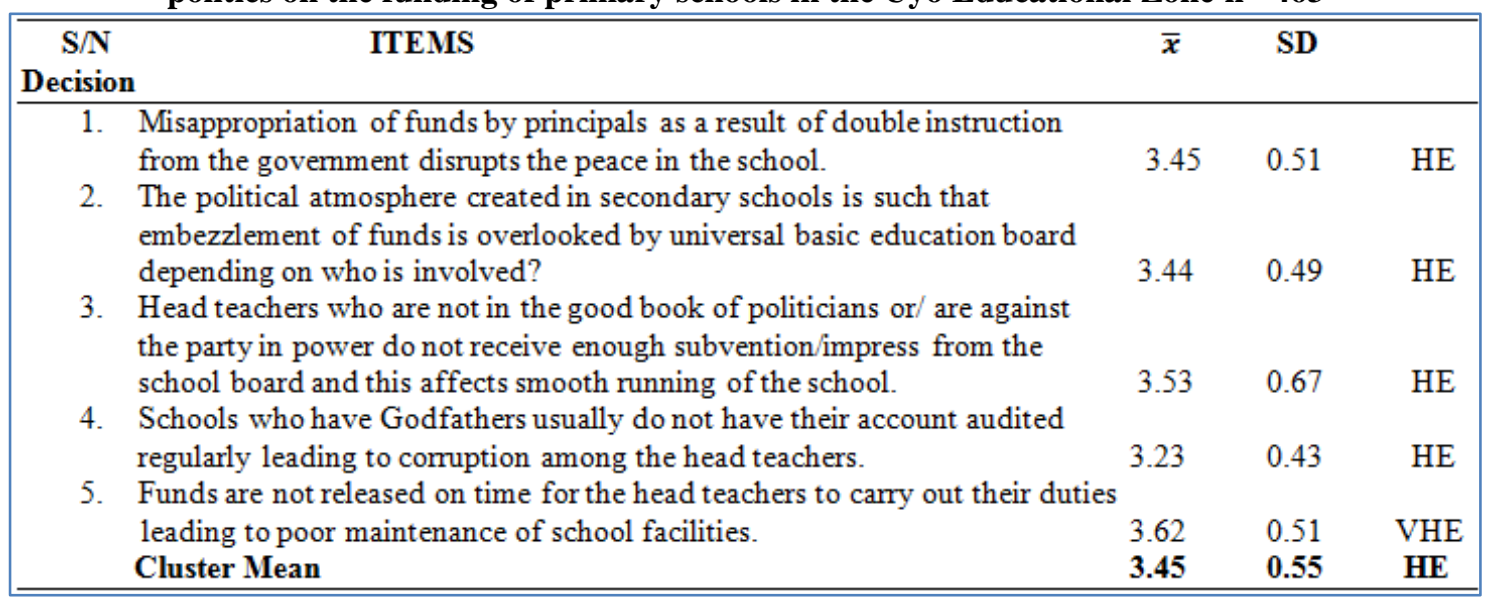

The data presented on Table 1 revealed the mean and standard deviation of head teachers and classroom teachers' responses on the influence of politics on the funding of primary schools with all the 5 items had their means ranging from 3.23 to 3.62 . These items are have their mean $(\bar{x})$ greater than the criterion mean of $2.50(\bar{x}>2.50)$ with a cluster mean of 3.45 which indicate a high extent on the influence of politics on the funding of primary schools in Uyo Educational Zone.

\section{Research Question 2}

To what extent do head teachers and classroom teachers' response on the influence of politics on the staff personnel administration of primary schools in Uyo Educational Zone?

Table-2: Mean and standard deviation of head teachers and classroom teachers' response on the influence of politics on the staff personnel administration of primary schools in Uyo Educational Zone $n=463$

\begin{tabular}{|c|c|c|c|c|}
\hline $\begin{array}{c}\mathrm{S} / \mathbf{N} \\
\text { Decision }\end{array}$ & ITEMS & $\overline{\boldsymbol{x}}$ & SD & \\
\hline 6. & $\begin{array}{l}\text { Government interference in the appointment secondary schools principals } \\
\text { causes bitterness among colleagues leading to poor teaching and learning } \\
\text { in the school. }\end{array}$ & 3.21 & 0.91 & $\mathrm{HE}$ \\
\hline & Discriminating disciplinary measures meted by school principals to staff & 311 & 084 & $\mathrm{HF}$ \\
\hline & $\begin{array}{l}\text { Favouritism employed in the promotion of staffleads to mediocrity in the } \\
\text { running of the school. }\end{array}$ & 2.57 & 0.76 & $\mathrm{HE}$ \\
\hline 9. & $\begin{array}{l}\text { Govermment interference in the appointment of principals makes some } \\
\text { principals autocratic in nature. } \\
\text { VHE }\end{array}$ & 3.73 & 0.99 & \\
\hline & $\begin{array}{l}\text { Inability of government to support the in-service training of staff affects } \\
\text { the competencies of such staff. }\end{array}$ & 3.34 & 0.65 & $\mathrm{HE}$ \\
\hline & Cluster Mean & 3.18 & 0.83 & HE \\
\hline
\end{tabular}

The data presented on Table 2 revealed the mean and standard deviation of head teachers and classroom teachers' responses on the influence of politics on the staff personnel administration of primary schools with all the 5 items had their means ranging from 2.57 to 3.73 . These items are have their mean $(\bar{x})$ greater than the criterion mean of $2.50(\bar{x}>2.50)$ with a cluster mean of 3.18 which indicate a high extent on the influence of politics on the staff personnel administration of primary schools in Uyo Educational Zone.

\section{Research Question 3}

To what extent do head teachers and classroom teachers' response on the influence of politics on the provision of basic infrastructure and equipment in primary schools in the Uyo Educational Zone? 
Table-3: Mean and standard deviation of head teachers and classroom teachers' response on the influence of politics on the provision of basic infrastructure and equipment in primary schools in Uyo Educational Zone $n=$ 463

\begin{tabular}{|c|c|c|c|c|}
\hline $\begin{array}{c}\mathrm{S} / \mathrm{N} \\
\text { Decision }\end{array}$ & ITEMS & $\overline{\boldsymbol{x}}$ & SD & \\
\hline & Quota system in the provision of equipment denies some schools of such & 299 & 076 & $\mathrm{HE}$ \\
\hline 12. & $\begin{array}{l}\text { There is uneven distribution of facilities due to the interest of party in } \\
\text { power leading to unconducive leaming environment. } \\
\text { VHE }\end{array}$ & 3.68 & 0.45 & \\
\hline & $\begin{array}{l}\text { Some schools are sited because of political interest leading to unequal } \\
\text { distribution of resources }\end{array}$ & 2.61 & 0.74 & $\mathrm{HE}$ \\
\hline 14. & $\begin{array}{l}\text { Some school equipment are diverted to personal use by prominent } \\
\text { members of the school community leading to scarcity of equipment in } \\
\text { the affected schools. }\end{array}$ & 3.48 & 0.99 & $\mathrm{HE}$ \\
\hline & $\begin{array}{l}\text { Contractors sometimes supply dilapidated equipment because they are } \\
\text { protected by (the powers that be) government and this discourages staff } \\
\text { from putting in their best. } \\
\text { VHE }\end{array}$ & 3.82 & 0.88 & \\
\hline & Cluster Mean & 3.32 & 0.76 & HE \\
\hline
\end{tabular}

The data presented on Table 3 revealed the mean and standard deviation of head teachers and classroom teachers' responses on the influence of politics on the provision of basic infrastructure and equipment in primary schools with all the 5 items had their means ranging from 2.99 to 3.82 . These items are have their mean $(\bar{x})$ greater than the criterion mean of $2.50(\bar{x}>2.50)$ with a cluster mean of 3.32 which indicate a high extent on the influence of politics on the provision of basic infrastructure and equipment in primary schools in Uyo Educational Zone.

\section{Research Question 4}

To what extent do head teachers and classroom teachers' response on the influence of politics on school community relations in primary schools in Uyo Educational Zone?

Table-4: Mean and standard deviation of head teachers and classroom teachers' response on the influence of politics on school community relations in primary schools in Uyo Educational Zone $n=463$

\begin{tabular}{|c|c|c|c|c|}
\hline \multicolumn{5}{|c|}{$\begin{array}{cc}\text { S/N } & \text { ITEMS } \\
\text { Decision } & \\
\end{array}$} \\
\hline 16. & $\begin{array}{l}\text { Teachers who have link with the government disrespect the school } \\
\text { authorities leading to carefree attitude to work. } \\
\text { VHE }\end{array}$ & 3.70 & 0.58 & \\
\hline & $\begin{array}{l}\text { As a result of political consideration, communities do not feel obliged to } \\
\text { honour invitation by the school head teachers. } \\
\text { VHE }\end{array}$ & 3.50 & 0.50 & \\
\hline 18. & $\begin{array}{l}\text { Marginalized member of the community in which schools are sited does } \\
\text { not offer substantial help to primary schools in the state leading to } \\
\text { misunderstanding between the community and the government. } \\
\text { VHE }\end{array}$ & 3.66 & 0.57 & \\
\hline 19. & $\begin{array}{l}\text { Communities leaving near primary schools are not allowed by the } \\
\text { school authorities to make use of school facilities resulting in school } \\
\text { community conflicts. } \\
\text { Primary school head teacher do not involve the communities in which their } \\
\text { schools are sited in important school activities leading to feeling of }\end{array}$ & 2.54 & 0.50 & $\mathrm{HE}$ \\
\hline & Marginalization by the communities. & 2.76 & 0.43 & $\mathrm{HE}$ \\
\hline & Cluster Mean & 3.23 & 0.52 & HE \\
\hline
\end{tabular}

The data presented on Table 3 revealed the mean and standard deviation of head teachers and classroom teachers' responses on the influence of politics on school community relations in primary schools with all the 5 items had their means ranging from 2.54 to 3.76 . These items are have their mean $(\bar{x})$ greater than the criterion mean of $2.50(\bar{x}>$ 2.50) with a cluster mean of 3.23 which indicate a high extent on the influence of politics on school community relations in primary schools in Uyo Educational Zone. 


\section{Hypotheses Testing}

Ho 1 There is no significant difference in the mean response scores of the head teachers and classroom teachers on the influence of politics on the funding of primary schools.

Table-5: t-test analysis of significant difference in the mean response scores of the head teachers and classroom teachers on the influence of politics on the funding of primary schools

\begin{tabular}{|l|l|c|l|l|l|l|l|}
\hline Variables & n & $\overline{\boldsymbol{x}}$ & SD & df & t-cal. & t-crit. & Decision \\
\hline Head teachers & 119 & 14.53 & 8.37 & & & & \\
\hline & & & & 461 & $3.812 *$ & 1.97 & Reject $\mathrm{H}_{1}$ \\
\hline Teachers & 344 & 12.02 & 3.36 & & & & \\
\hline
\end{tabular}

The result in Table 5 showed that t-calculated value of 3.812 with an associated t-critical value of 1.97 was obtained with regards to the significant difference in the mean response scores of the head teachers and classroom teachers on the influence of politics on the funding of primary schools. Since the t-calculated value was greater than tcritical value, the null hypothesis one which states that there is no significant difference in the mean response scores of the head teachers and classroom teachers on the influence of politics on the funding of primary schools was rejected. This implies that there is a significant difference in the mean response scores of the head teachers and classroom teachers on the influence of politics on the funding of primary schools in Uyo Educational Zone.

H02: There is no significant difference in the mean response scores of the head teachers and classroom teachers on the influence of staff personnel administration of primary schools.

Table-6: t-test analysis of significant difference in the mean response scores of the head teachers and classroom teachers on the influence of politics on staff personnel administration of primary schools

\begin{tabular}{|l|l|c|l|l|l|l|l|}
\hline Variables & $\mathbf{n}$ & $\overline{\boldsymbol{x}}$ & SD & df & t-cal. & t-crit. & Decision \\
\hline Head teachers & 119 & 13.32 & 3.50 & & & & \\
\hline & & & & 461 & $3.741^{*}$ & 1.97 & Reject $\mathrm{H}_{2}$ \\
\hline Teachers & 344 & 11.22 & 3.16 & & & & \\
\hline
\end{tabular}

The result in Table 6 showed that $t$-calculated value of 3.741 with an associated t-critical value of 1.97 was obtained with regards to the significant difference in the mean response scores of the head teachers and classroom teachers on the influence of politics on staff personnel administration of primary schools. Since the t-calculated value was greater than t-critical value, the null hypothesis one which states that there is no significant difference in the mean response scores of the head teachers and classroom teachers on the influence of politics on staff personnel administration of primary schools was rejected. This implies that there is a significant difference in the mean response scores of the head teachers and classroom teachers on the influence of politics on staff personnel administration of primary schools in Uyo Educational Zone.

H03: There is no significant difference in the mean response scores of the head teachers and classroom teachers on the influence of provision of basic infrastructure and equipment in primary schools.

Table-7: t-test analysis of significant difference in the mean response scores of the head teachers and classroom teachers on the influence of politics on provision of basic infrastructure and equipment in primary schools

\begin{tabular}{|l|l|c|l|l|l|l|l|}
\hline Variables & $\mathbf{n}$ & $\overline{\boldsymbol{x}}$ & SD & df & t-cal. & t-crit. & Decision \\
\hline Head teachers & 119 & 14.09 & 3.27 & & & & \\
\hline & & & & 461 & $6.038^{*}$ & 1.97 & Reject $\mathrm{H}_{3}$ \\
\hline Teachers & 344 & 13.32 & 3.50 & & & & \\
\hline
\end{tabular}

The result in Table 7 showed that t-calculated value of 6.038 with an associated t-critical value of 1.97 was obtained with regards to the significant difference in the mean response scores of the head teachers and classroom teachers on the influence of politics on provision of basic infrastructure and equipment in primary schools. Since the tcalculated value was greater than t-critical value, the null hypothesis one which states that there is no significant difference in the mean response scores of the head teachers and classroom teachers on the influence of politics on provision of basic infrastructure and equipment in primary schools was rejected. This implies that there is a significant difference in the mean response scores of the head teachers and classroom teachers on the influence of politics on provision of basic infrastructure and equipment in primary schools in Uyo Educational Zone. 
$\mathbf{H 0}_{4}$ There is no significant difference in the mean response scores of the head teachers and classroom teachers on the influence of school community relations in primary schools.

\begin{tabular}{l} 
Table-7: t-test analysis of significant difference in the mean response scores of the head teachers and classroom \\
teachers on the influence of politics on school community relations in primary schools \\
$\qquad$\begin{tabular}{|l|c|c|c|c|c|c|c|}
\hline Variables & $\mathbf{n}$ & $\overline{\boldsymbol{x}}$ & SD & $\mathbf{d f}$ & $\mathbf{t}$-cal. & t-crit. & Decision \\
\hline Head teachers & 119 & 14.06 & 3.37 & & & & \\
\hline & & & & 461 & $2.276^{*}$ & 1.97 & Reject $\mathrm{H}_{4}$ \\
\hline Teachers & 344 & 13.32 & 3.50 & & & & \\
\hline
\end{tabular} \\
\hline
\end{tabular}

The result in Table 7 showed that t-calculated value of 2.276 with an associated t-critical value of 1.97 was obtained with regards to the significant difference in the mean response scores of the head teachers and classroom teachers on the influence of politics on school community relations in primary schools. Since the t-calculated value was greater than t-critical value, the null hypothesis one which states that there is no significant difference in the mean response scores of the head teachers and classroom teachers on the influence of politics on school community relations in primary schools was rejected. This implies that there is a significant difference in the mean response scores of the head teachers and classroom teachers on the influence of politics on school community relations in primary schools in Uyo Educational Zone.

\section{DisCUSSION OF FINDINGS}

In hypothesis one it was found that there is a significant difference in the mean response scores of the head teachers and classroom teachers on the influence of politics on the funding of primary schools. This is because head teachers and classroom teachers' response indicated a high extent the influence of politics on the influence of politics on the funding of secondary school in that misappropriation of funds by head teachers disrupts peace in the school, head teachers who are not on the good book of politicians or those against the party in power do not receive enough imprest from the school board and there is favouristism in the disbursement of fund leads to conflict in schools. This finding agrees with the initial finding of Ogbonnaya [1], that with procuring, expending, accounting and maintaining the financial resources of an educational institution efficiently to achieve educational objectives. The achievements of educational goals depends on adequate financial support of the government, organizations, individual and even communities, because adequate financial supply and maintenance makes the school to reach its glory and ensure adequate personnel to work in an organization. In order to achieve the stated objectives of school management, there is the need for adequate staff personnel management to work in the organization.

Hypothesis two found a significant difference in the mean response scores of the head teachers and classroom teachers on the influence of politics on staff personnel administration of primary schools. This is because head teachers and classroom teachers' response indicated a high extent the influence of politics on the influence of politics on staff personnel administration of primary schools in that preferential appointment of principals by government generates conflicts in schools, recruitment of unqualified teachers in primary schools show some bias in favour of the local community. This finding is in line with that of Oboegbulem [8] who asserted that staff personnel administration as the manpower or human resources management in an organization and which embraces recruitment of staff, staff maintenance, selection, induction, motivation, appraisal, developmental, discipline, training, compensations and evaluation of staff for education activities. In a school system, the overall goals of the personnel administration is to recruit adequate and qualified staff, develop and maintain the staff so that they would be able and willing to render effective and efficient educational services to the pupils.

Also, in hypothesis one it was found that there is a significant difference in the mean response scores of the head teachers and classroom teachers on the influence of politics on provision of basic infrastructure and equipment in primary schools. This finding was so because head teachers and classroom teachers' response indicated a high extent in that quota system in the provision of computer denies some schools of such equipment, government interest determines where primary schools are sited and there is uneven distribution of facilities to the interest of the party in power. The findings of this present study support [9] who asserted that activities of the schools are evaluated and expressed through the quality of facilities in the school e.g. the quality of teachers, building, playground, and computers and so on. These respondents seem to believe that politics affected the provision, development, procurement and maintenance of infrastructural facilities in Uyo Educational Zone. 
Again, in hypothesis four it was found that there is a there is a significant difference in the mean response scores of the head teachers and classroom teachers on the influence of politics on school community relations in primary schools. Head teachers and classroom teachers' response indicated a high extent in the administrative task area of school community relations and teachers who have link with the government disrespect the school authorities leading to carefree attitude. This is in line with views of Ogbonnaya [5] that the relationship between the school, the community and the ruling political parties are guided by policies and decision which affect the school management positively/or negatively. It has been observed that interference of government is having some influences on the management and policies that guide school management. No school can operate in a vacuum without the society or the community it serves. Obegbulem [8] said that a close study of the community affords the teachers a superior understanding of the background of the students. They are thus able to know the ability of each child and know how to handle each child according to his or her abilities.

\section{CONCLUSION}

Education is very important in every nation of the world but it is usually influenced in various ways and politics is one of the ways. The purpose of this study was to determine the influences of politics on the management of primary schools in Uyo Educational Zone. It is observed that (politics) influences government interference in primary education in funding, staff-personnel administration, provision of basic infrastructures/equipment, and school community relations. The findings of the study revealed a high extent on the influence of politics on the management of primary schools. Also, a significant difference in the mean response scores of the head teachers and classroom teachers on the influence of politics on the management of primary schools.

\section{Implications of Politics in Management of primary Schools for National Development}

Politics cannot be separated from primary school management. It is for this reason that Okeke [2] stated emphatically that politics plays an important role in decision making, control and governance of primary schools. Politics in education can be looked at as a process of control, decision making, implementation, management, governance and a method by which resources are allocated to different ethnic groups to achieve their aims. The role of politics is heightened in view of the fact that an educational system has political goals and these goals are essential to justify the existence of the system and the political order of society. In other words, the political order initiates good education.

First, national development requires total commitment on the parts of the leadership. The need for discipline and honesty on the part of the school management cannot be compromised; such officials should show enough discipline, interest, willingness, dedication and honesty. Without these attributes and the will to pursue set economic goals, all other ingredients of development present would amount to nullity.

Also, stability and continuity of policies encourage investment and propel development. For instance, in Korea, when park was assassinated, his policies remained and were building on. Nigeria leadership must learn to build on policies rather than to jettison them for new ones for the sake of party politics and personal aggrandisement. Human resources development is also a sine qua non to Nigeria national development. Development depends very much on human knowledge and skills. This must be such that a high quality of education and training is achieved for a large majority at a reasonable price and the context and quality of such education and training should be relevant and adequate to the country's development needs. Importantly, citizenship should be promoted over indigeneity in order to achieve cooperation and participation of all communities in the development process.

\section{RECOMMENDATIONS}

Based on the results of the study, the following recommendations are made:

1. Local governments should ensure that there is no favouritism in the disbursement of funds in primary schools; this politics is bound to adversely affect the provision of management of funds in primary schools.

2. The Local Education Authority in the different Local Government Areas should eschew preferential appointments of head teachers as this generates conflict in schools. Also, the issue of favouritism in the appointment of staff to work in the school system should be avoided since this lead to appointment of mediocres in the system.

3. The states governments should avoid quota system in the provision of facilities and equipment in schools. This is because these leads to differentials in the quality and quantity of schools.

4. Good school community relationship should be maintained and strengthened; the school head Should also try as much as possible to have more knowledge of the community by interacting with its members 


\section{REFERENCES}

1. Ogbonnaya, N.O. (2002). Management and maintenance of physical facilities. International Journal of Education Development: 4(1), $208-213$.

2. Okeke, B. S. (2007). Politics of education: The Nigeria Experience. Awka: Doone Printing \& Publishing.

3. Ogbonnaya, N.O. (2009). Social and political contexts of educational administration and planning. Nsukka: Chuka Educational Publishers.

4. Uchendu, P. K. (1995). Education and the changing economic role of Nigerian women.

5. Ogbonnaya, N.O. (2006). Principles and application of educational policies in Nigeria. Nsukka: University Trust Publishers.

6. Peretomode, V. F. (1999). Educational administration. Applied Concepts and Theoretical Perspectives. Lagos: Joja Educational Research and Publication Limited.

7. Ezeocha, P. A. (1990). Education administration and planning. Nsukka: Optimal Computer Solution Ltd.

8. Oboegbulem, A.I. (2004). Conflict and stress in the secondary school system: implications for the administrator. ESUT Journal of Education, 2(1), 7 - 14).

9. Mgbodile, T. O. (2003). Fundamentals in educational administration and planning. Enugu: Magnet Business Enterprises.

10. Eze, A. (2002). Computer based information technology for management of teacher education of the UBE in philosophy and Education. Enugu. Snaap Limited.

CITATION: Ndifreke Okon Jonah et al (2021). Politics and Management of Primary Schools in Uyo Educational Zone: Implications for National Development. South Asian Res J Human Soc Sci, 3(1): 12-21. 